\title{
Mikrozonasi Seismik Wilayah Padalarang, Kabupaten Bandung Barat Menggunakan Metode Horizontal to Vertical Spectral Ratio (HVSR)
}

\author{
Gabrio Hikma Januarta ${ }^{1 *}$, Tedi Yudistira ${ }^{2}$, Adrin Tohari ${ }^{3}$, Erlangga Ibrahim \\ Fattah $^{1}$ \\ ${ }^{1}$ Program Studi Teknik Geofisika, Institut Teknologi Sumatera, Kabupaten Lampung Selatan, \\ Lampung 35365 \\ ${ }^{2}$ Institut Teknologi Bandung, Jl. Ganesha 10, Bandung, Jawa Barat 40132 \\ ${ }^{3}$ Pusat Penelitian Geoteknologi LIPI, Jl. Sangkuriang, Bandung, Jawa Barat 40135
}

\begin{abstract}
ABSTRAK Dalam kurun waktu lima tahun terakhir terjadi peningkatan aktivitas tektonik di wilayah selatan Pulau Jawa. Salah satu sesar aktif di wilayah Jawa Barat yaitu Sesar Cimandiri dan Sesar Lembang. Sesar Cimandiri berarah barat daya-timur laut, sedangkan Sesar Lembang berarah timur-barat. Melalui citra satelit DEM (Digital Elevation Model) pertemuan kedua sesar diduga berada di wilayah Padalarang, Kabupaten Bandung Barat. Keberadaan infrastruktur penghubung kota seperti jalan tol, rel kereta api serta permukiman penduduk yang padat menjadikan daerah tersebut merupakan daerah yang berpotensi mengalami kerusakaan saat terjadi gempa bumi. Dalam upaya mitigasi diperlukan studi mikrozonasi untuk mengetahui karakteristik tanah. Metode Horizontal to Vertical Spectral Ratio (HVSR) digunakan untuk mengestimasi nilai frekuensi dominan $\left(f_{0}\right)$ dan faktor amplifikasi $\left(A_{0}\right)$ daerah setempat dari data pengukuran mikrotremor. Dari 42 titik pengukuran didapatkan nilai frekuensi dominan $\left(f_{0}\right)$ yang terbagi kedalam dua zona yaitu $1,4-3,5$
\end{abstract}

Naskah masuk : 14 Januari 2020

Naskah direvisi : 15 September 2020

Naskah diterima : 3 Oktober 2020

*Penulis korespondensi.

Email: gabriohikmajanuarta@gmail.com
$\mathrm{Hz}$ dan 3,5-6 Hz. Sedangkan nilai faktor amplifikasi $\left(A_{0}\right)$ berkisar antara $2-8$. Nilai indeks kerentanan seismik $\left(K_{g}\right)$ berkisar antara 1-30, daerah dengan indeks kerentanan seismik $\left(K_{g}\right)$ sedang hingga tinggi berada di Kecamatan Ngamprah dan Kecamatan Cisarua, sedangkan indeks kerentanan seismik $\left(K_{g}\right)$ pada daerah Kecamatan Padalarang relatif rendah hingga sedang.

Kata kunci: mikrozonasi, mikrotremor, HVSR, Sesar Lembang, Sesar Cimandiri,

\begin{abstract}
Seismic Microzonation of Padalarang District, West Bandung Regency Using Horizontal to Vertical Spectral Ratio (HVSR) Method. In the last five years, tectonic activity has increased in the southern region of Java Island. One of the active faults in West Java region is Cimandiri Fault and Lembang Fault. The Cimandiri Fault is southwest-northeast, while the Lembang Fault is east-west. Through DEM (Digital Elevation Model) satellite imagery, the intersection of the faults is probably located in Padalarang, West Bandung Regency. The existence of urban infrastructures such as toll roads, railways, and dense settlements makes this area have the potential to experience damage during an earthquake. Therefore, in mitigation efforts, microzonation studies are needed to determine the dynamic characteristics of soils in the area. Horizontal to Vertical Spectral Ratio (HVSR) method is used to estimate the value of dominant frequency $\left(f_{0}\right)$ and the amplification factor $\left(A_{0}\right)$ from microtremor measurement data. From 42 measurement points, the dominant frequency value $\left(f_{0}\right)$ is divided into two zones, 1.4-
\end{abstract}


$3.5 \mathrm{~Hz}$ and $3.5-6 \mathrm{~Hz}$. The amplification factor $\left(A_{0}\right)$ ranges from 2-8. The value of the seismic vulnerability index $\left(K_{g}\right)$ ranges from $1-30$; areas with moderate to high seismic vulnerability indexes are in Ngamprah and Cisarua Districts, while the seismic vulnerability index in the Padalarang District is relatively low to moderate.

Keywords:, microzonation, microtremor, HVSR, Lembang Fault, Cimandiri Fault

\section{PENDAHULUAN}

Indonesia merupakan zona sesar aktif dengan aktivitas tektonik yang tinggi. Aktivitas tektonik di Indonesia dipengaruhi oleh pergerakan lempeng seperti: Lempeng Eurasia, Lempeng Indo-Australia, dan Lempeng Pasifik. Mekanisme pergerakan sesar menjadi salah satu penyebab terjadinya gempa bumi. Salah satu sesar aktif di wilayah Jawa Barat yaitu Sesar Cimandiri dan Sesar Lembang. Sesar Cimandiri berarah barat daya-timur laut, sedangkan Sesar Lembang berarah timur-barat. Melalui citra data DEM (Digital Elevation Model) pertemuan kedua sesar diduga berada di wilayah Padalarang-Ngamprah. Zona pertemuan kedua sesar ini menjadi potensi bahaya gempa bumi yang sangat tinggi, di mana lokasi tersebut sangat dekat dengan permukiman penduduk yang padat serta terdapat infrastruktur transportasi seperti jalan tol dan rel kereta api.

Menurut Daryono et al. (2019) hingga saat ini Sesar Lembang masih aktif dengan kecepatan geser 3 sampai $5,5 \mathrm{~mm} /$ tahun. Titik nol sesar berada di daerah Padalarang dekat jalan Tol Purbaleunyi dengan total panjang sesar $29 \mathrm{Km}$. Jika seluruh segmen Sesar Lembang tersebut bergerak maka diperkirakan dapat menghasilkan gempa dengan magnitudo $M_{w}$ 6,5 hingga 7,0. Dalam upaya mitigasi bencana diperlukan studi mikrozonasi untuk mengetahui karakteristik tanah. Nakamura (2000) menyatakan daerah yang mengalami tingkat kerusakan yang tinggi akibat gempa bumi terjadi pada dataran aluvial yang tersusun oleh material sedimen yang memiliki nilai indeks kerentanan seismik $\left(K_{g}\right)$ yang tinggi berkisar antara 20-100. Selain itu berdasarkan penelitian Daryono (2013) dari hasil analisis nilai indeks kerentanan seismik $\left(K_{g}\right)$ di zona Graben Bantul, daerah dengan indeks kerentanan seismik $\left(K_{g}\right)$ dengan nilai 21,2 memiliki rasio kerusakan sebesar $77 \%$. Adanya kemiripan pola antara indeks kerentanan seismik $\left(K_{g}\right)$ dengan tingkat kerusakan bangunan ini menjadi dasar perlu dilakukannya studi mikrozonasi seismik untuk mengetahui zonasi nilai indeks kerentanan seismik $\left(K_{g}\right)$ di daerah penelitian.

\section{KONDISI GEOLOGI}

Secara umum daerah penelitian merupakan daerah sedimentasi dengan suplai sedimen berasal dari Gunung Tangkubanparahu (Van Bemmelen, 1949). Gambar 1 merupakan peta geologi daerah penelitian. Peta tersebut menunjukkan litologi pada daerah penelitian yang terbagi kedalam tiga kelompok satuan batuan yaitu:

(1) Pasir tufan (Qyd). Satuan litologi ini ditandai dengan warna abu-abu pada Gambar 1. Litologi pada satuan batuan ini terdiri dari tufan kasar dengan fragmen batuan beku dan tuf, lahar lapuk kemerah-merahan dan lapisan-lapisan lapili serta breksi. Tufan pada satuan ini berasal dari erupsi gunung Dano dan gunung Tangkubanparahu dengan ketebalan lapisan berkisar 0-100 m (Van Bemmelen 1934).

(2) Tuf berbatu apung (Qyt). Satuan litologi ini ditandai dengan warna biru muda pada Gambar 1, dan mendominasi area penelitian. Berasal dari erupsi gunung Tangkubanparahu yang terdiri dari pasir tufan, lapilli dan lapisan kaya batuapung, dan mempunyai ketebalan sekitar 40m (Van Bemmelen 1934).

(3) Breksi (Qob). Satuan litologi ini ditandai dengan warna ungu pada Gambar 1. Geomorfologi perbukitan mendominasi daerah utara penelitian dengan relief tinggi serta aliran sungai yang dalam. Litologi pada satuan ini tergolong lebih tua yang terdiri dari endapan lahar, lava dan breksi vulkanik dengan fragmen batuan beku menyudut serta matriks pasir dan tuf dengan ketebalan lapisan 0-150 m (Van Bemmelen, 1934).

\section{METODE}

\section{Akuisisi data mikrotremor}

Daerah penelitian secara administratif terletak di Kabupaten Bandung Barat, Provinsi Jawa Barat yang terbagi kedalam tiga kecamatan yaitu Kecamatan Padalarang, Kecamatan Ngamprah, dan Kecamatan Cisarua. Terdapat total 42 titik pengukuran mikrotremor dengan spasi pengukuran terdekat berkisar 200-300 m dan 


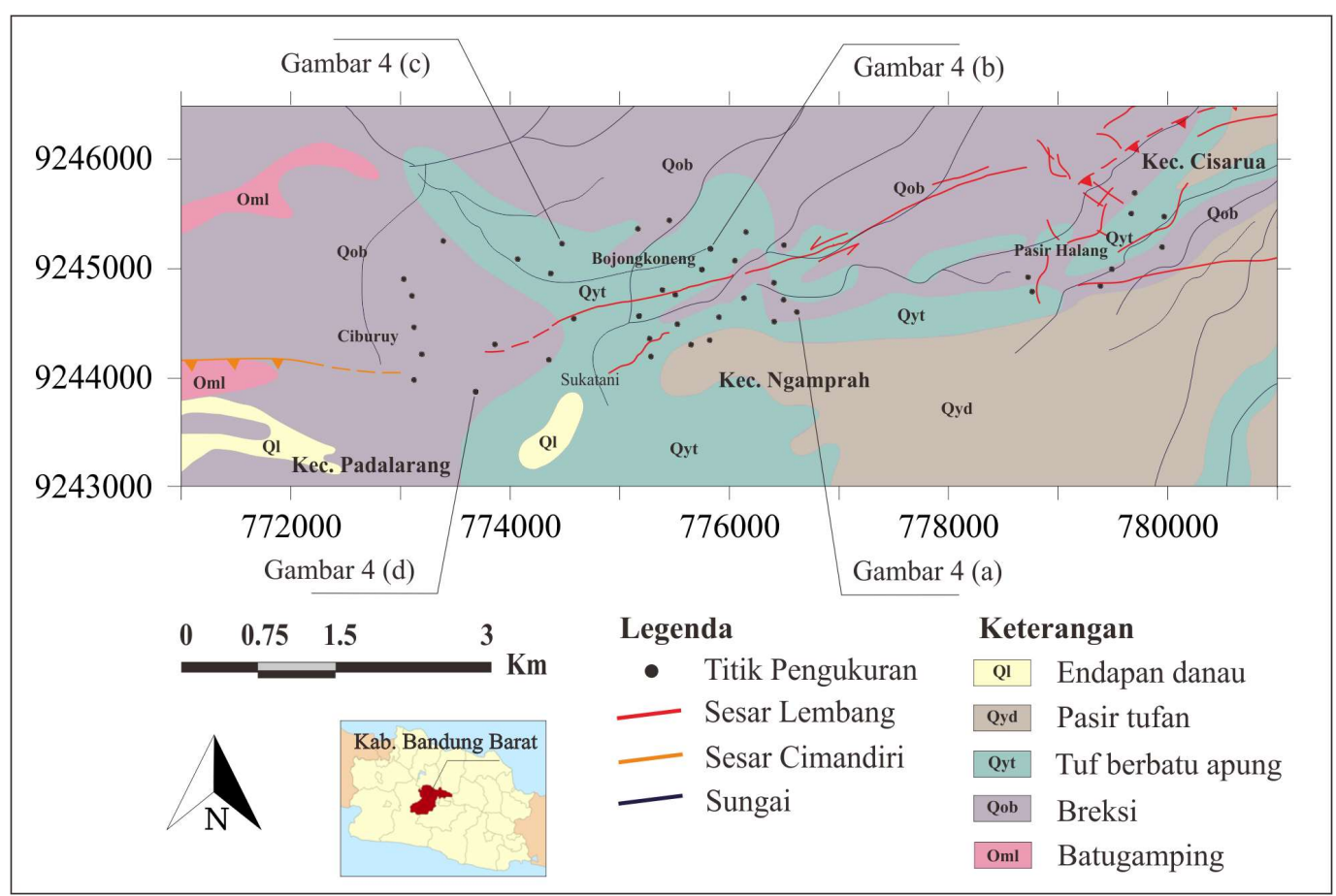

Gambar 1. Peta geologi daerah zona Sesar Lembang dan Sesar Cimandiri (modifikasi dari Silitonga (1973) dan Sudjatmiko (1972)), dan sebaran titik-titik pengukuran mikrotremor.

spasi terjauh berkisar 400-500 m. 27 titik pengukuran berada di Kecamatan Ngamprah tepatnya disekitar jalan tol Purbaleunyi, 7 titik di wilayah Situ Ciburuy Kecamatan Padalarang dan 8 titik di Desa Pasirhalang Kecamatan Cisarua (Gambar 1). Penentuan titik pengukuran difokuskan pada wilayah dugaan pertemuan kedua sesar.

\section{Pengolahan data mikrotremor}

Hasil pengukuran data mikrotremor dilapangan tercatat dalam fungsi waktu. Data tersebut terdiri dari 3 komponen yaitu dua spektrum komponen horizontal dengan arah east-west dan north-south dan satu spektrum komponen vertikal dengan arah up-down. Adapun format data pengukuran yaitu SG2. Selanjutnya dilakukan pengolahan data mengunakan software GEOPSY, data tersebut berupa waveform gelombang 3 komponen seperti pada Gambar 2a. Kemudian pada software tersebut terlebih dahulu dilakukan proses pemisahan antara gelombang mikrotremor dengan noise yang terekam pada data. Proses ini dikenal dengan istilah windowing seperti pada Gambar $2 \mathrm{~b}$. Proses ini dilakukan secara otomatis dengan menggunakan parameter inputan berupa nilai panjang window (window length), STA (short term average), LTA (long term average) pada $\mathrm{H} / \mathrm{V}$ toolbox (Gambar 3 (kiri)). Penentuan parameter inputan dilakukan berdasarkan trial and error, di mana nilai parameter inputan yang dapat memisahkan antara gelombang mikrotremor dan noise dengan baik adalah nilai inputan yang digunakan. Selain itu untuk meningkatkan hasil koreksi noise pada data juga dilakukan proses windowing manual dengan memilih data yang dianggap noise secara manual berdasarkan catatan harian pengukuran mengenai aktivitas disekitar titik pengukuran (lalu lintas kendaraan dan aktivitas pejalan kaki). Selanjutnya dilakukan transformasi data untuk mengubah data dalam fungsi waktu menjadi fungsi frekuensi. Proses ini menggunakan tools $\mathrm{H} / \mathrm{V}$ yang tersedia pada software dengan algoritma transformasi yang digunakan yaitu Fast Fourier Transform (FFT). Kemudian masing-masing spektrum fourier komponen horizontal di jumlahkan dengan akar rata-rata kuadrat dan dibagi dengan spektrum vertikal yang secara matematis dituliskan sebagai berikut: 


$$
H V S R=\frac{\sqrt{S^{2}{ }_{N S}(f)+S^{2}{ }_{E W}(f)}}{S_{U D}(f)},
$$

di mana HVSR adalah horizontal to vertical spectral ratio, $S_{N S}$ adalah spektrum komponen horizontal dengan arah north-south, $S_{E W}$ adalah spektrum komponen horizontal dengan arah eastwest, dan $S_{U D}$ adalah spektrum komponen vertikal dengan arah up-down.

Metode HVSR digunakan untuk mengestimasi nilai frekuensi dominan $\left(f_{0}\right)$ dan nilai faktor amplifikasi $\left(A_{0}\right)$ dari puncak kurva $\mathrm{H} / \mathrm{V}$ (Nakamura, 1989). Gambar 3 (kanan) merupakan hasil kurva $\mathrm{H} / \mathrm{V}$, di mana proyeksi puncak kurva
$\mathrm{H} / \mathrm{V}$ pada sumbu $\mathrm{X}$ merupakan nilai frekuensi dominan $\left(f_{0}\right)$, sedangkan titik puncak kurva pada sumbu Y merupakan nilai faktor amplifikasi $\left(A_{0}\right)$. Kedua parameter tersebut digunakan untuk menghitung nilai indeks kerentanan seismik $\left(K_{g}\right)$. Indeks kerentanan seismik $\left(K_{g}\right)$ merupakan suatu parameter yang berhubungan dengan tingkat kerawanan suatu wilayah saat terjadi gempa (Nakamura, 2000) yang secara matematis dinyatakan sebagai berikut:

$$
K g=\frac{A_{0}^{2}}{f_{0}}
$$

di mana $A_{0}$ adalah faktor amplifikasi dan $f_{0}$ adalah frekuensi dominan.

(a)

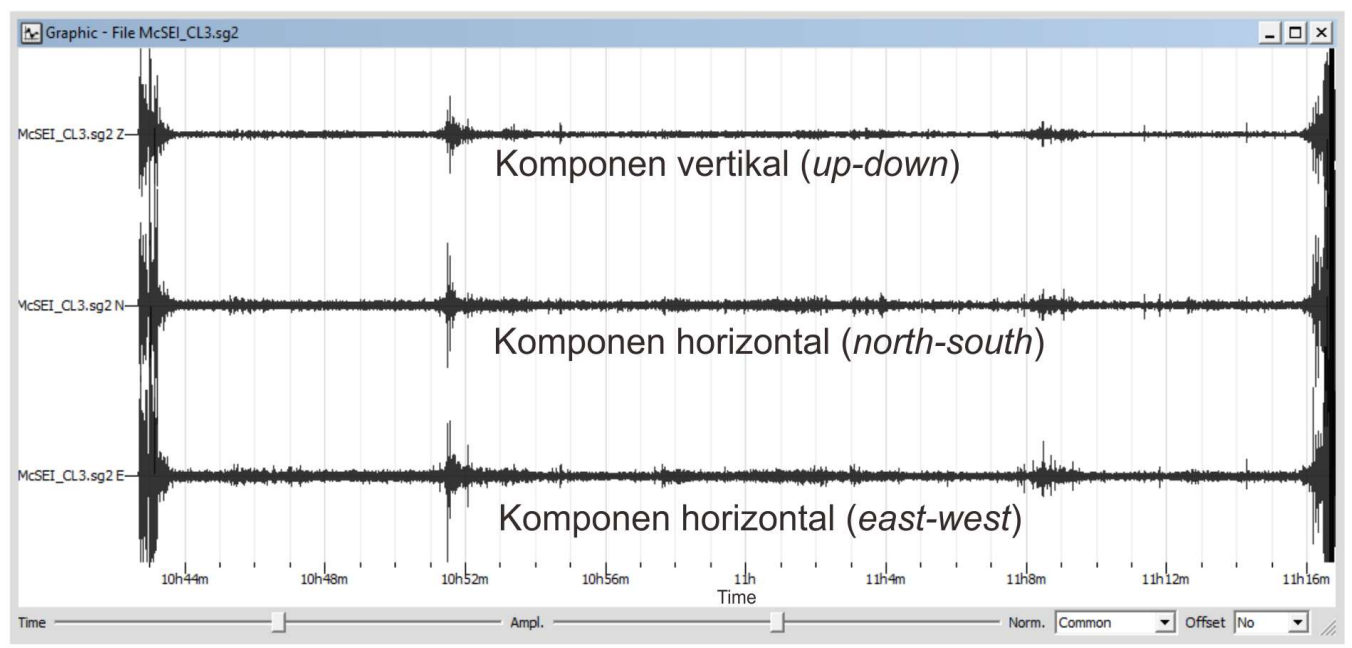

(b)

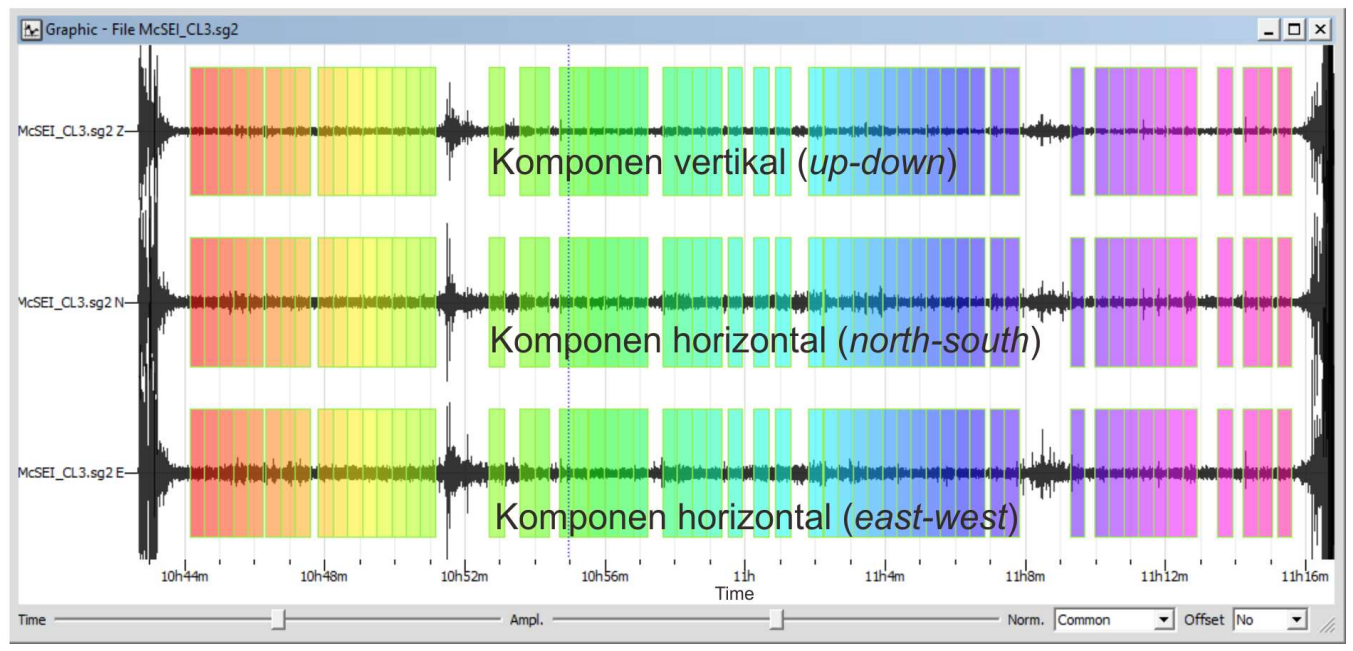

Gambar 2. (a) Waveform gelombang mikrotremor 3 komponen terdiri dari 2 komponen horizontal dengan arah east-west dan north-south dan 1 spektrum komponen vertikal dengan arah up-down. (b) Proses windowing (memisahkan noise gelombang) pada data CL3. 


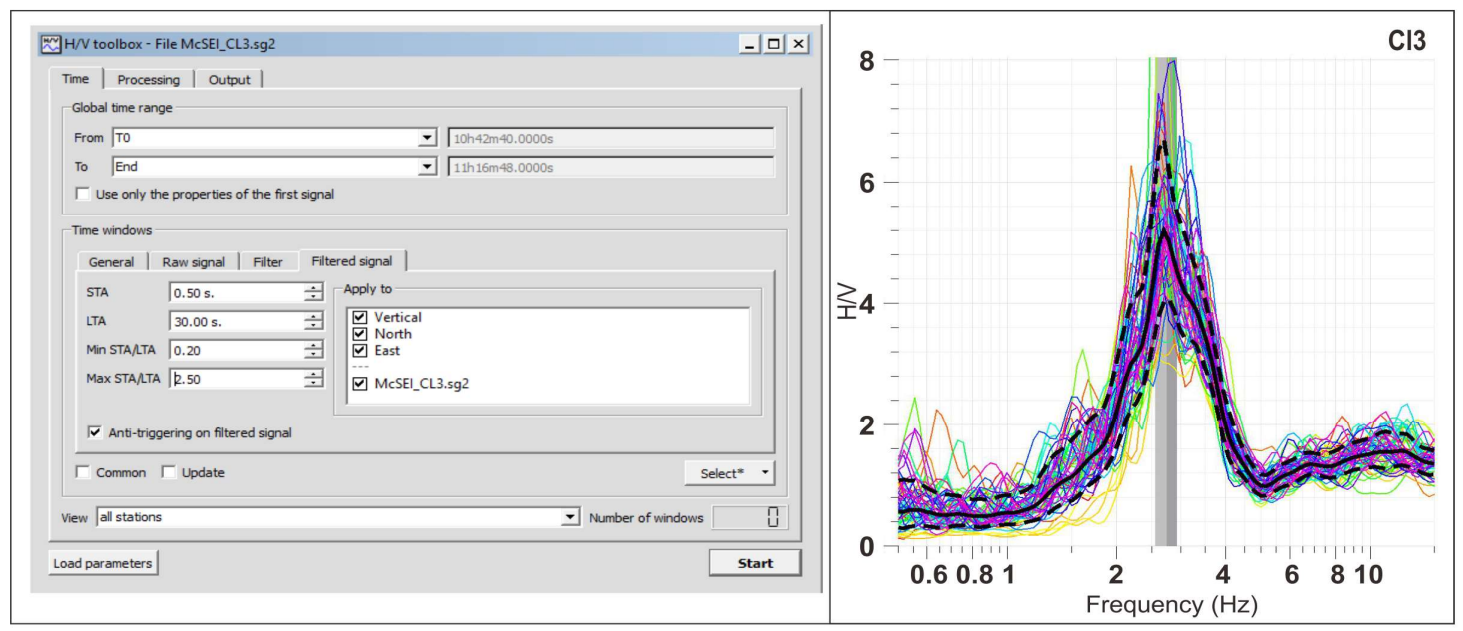

Gambar 3. Tampilan H/V toolbox untuk melakukan proses windowing automatis dengan memasukkan parameter inputan time windows (kiri), dan contoh kurva H/V data CL3 dengan sumbu $\mathrm{x}$ merupakan frekuensi dan sumbu y merupakan H/V (kanan).

\section{HASIL}

\section{Karakteristik kurva H/V}

Sebelum dilakukan analisis pada kurva $\mathrm{H} / \mathrm{V}$ terlebih dahulu dilakukan pengecekan kriteria realibilitas kurva yang merujuk pada standar SESAME European Research Project (SESAME, 2004). Gambar 4 merupakan beberapa kurva H/V yang telah memenuhi kriteria reliabilitas dan dapat dikategorikan kedalam kurva clear peak dan unclear peak sebagaimana disajikan pada Tabel 1 .

Tabel 1. Pengelompokan kurva H/V berdasarkan jenis puncak.

\begin{tabular}{lll}
\hline No & Jenis & Titik Pengukuran \\
\hline 1 & Clear peak & $2,3,4,5,6,10,11$, \\
& & $12,13,21,23,28$, \\
& & $30,38,42$ \\
\hline 2 & Unclear broad & $18,19,22,24,25$, \\
& peak & $26,27,29,34,35$, \\
& & 40 \\
\hline 3 & Unclear sharp & $7,9,14,16,17,20$, \\
& peak & $36,37,43,45$ \\
\hline 4 & Unclear two peak & $1,15,31,32,33,41$ \\
\hline
\end{tabular}

\section{Analisis frekuensi dominan $\left(f_{0}\right)$}

Gambar 5 menyajikan peta persebaran nilai frekuensi dominan $\left(f_{0}\right)$ pada daerah penelitian, yang memperlihatkan rentang nilai frekuensi dominan $\left(f_{0}\right)$ berkisar antara 1 dan $6 \mathrm{~Hz}$. Secara umum nilai frekuensi dominan $\left(f_{0}\right)$ yang relatif kecil berada pada dataran kaki gunung dan perbukitan struktural, sedangkan nilai frekuensi dominan $\left(f_{0}\right)$ yang tinggi berada pada bentuk lahan lereng bukit yang telah mengalami pengikisan. Parolai et al. (2007) menyatakan bahwa frekuensi dominan $\left(f_{0}\right)$ erat hubungannya dengan kedalaman batuan dasar. Keduanya memiliki hubungan berbanding terbalik, artinya nilai frekuensi dominan $\left(f_{0}\right)$ yang rendah berasosiasi dengan kedalaman batuan dasar yang dalam. Geomorfologi daerah pegunungan di sebelah timur daerah penelitian memperlihatkan sebaran endapan yang cukup tebal yaitu pada satuan litologi pasir tufan (Qyd) dan tufan berbatu apung (Qyt) yang ditunjukkan dengan nilai rentang frekuensi dominan $\left(f_{0}\right)$ yang rendah yaitu antara 1,4-3,5 Hz. Sedangkan daerah utara penelitian menunjukkan nilai frekuensi dominan $\left(f_{0}\right)$ yang relatif lebih tinggi 3,5-6 Hz dan terasosiasi dengan satuan litologi breksi (Qob). Hal ini mengindikasikan bahwa lapisan breksi tersebut lebih tipis dibandingkan lapisan tufan. Dengan demikian selain kondisi litologi, sebaran nilai 
(a)

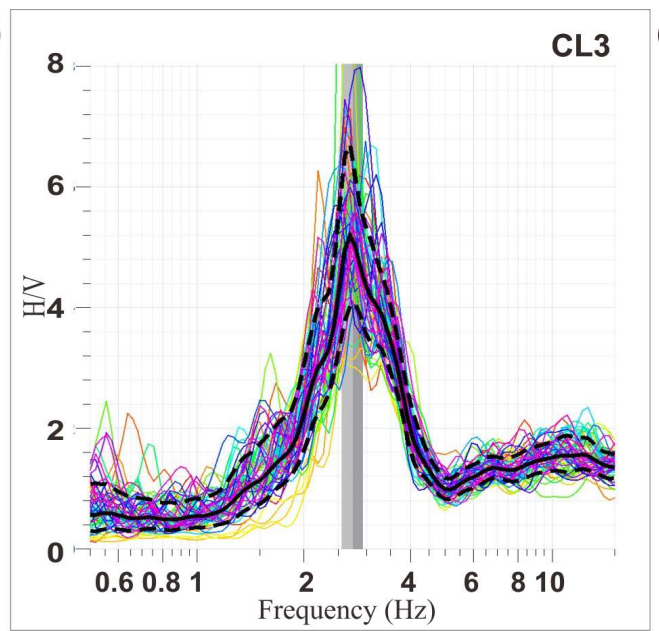

Clear peak

(c)

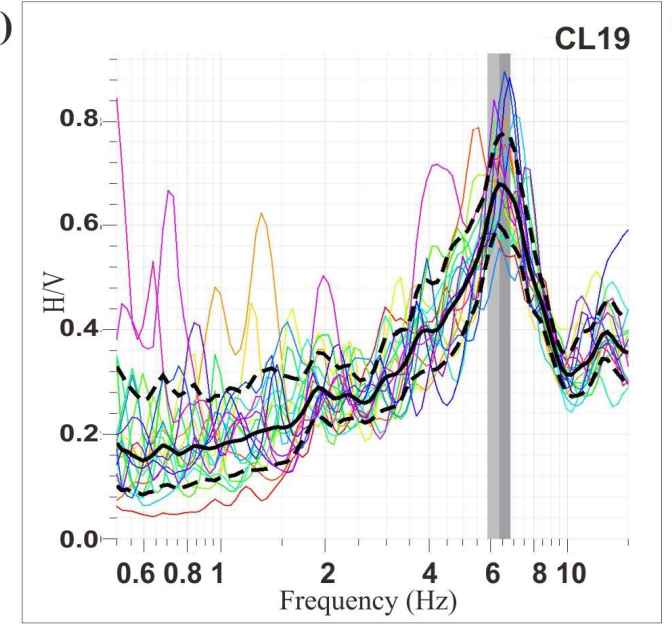

Unclear board peak

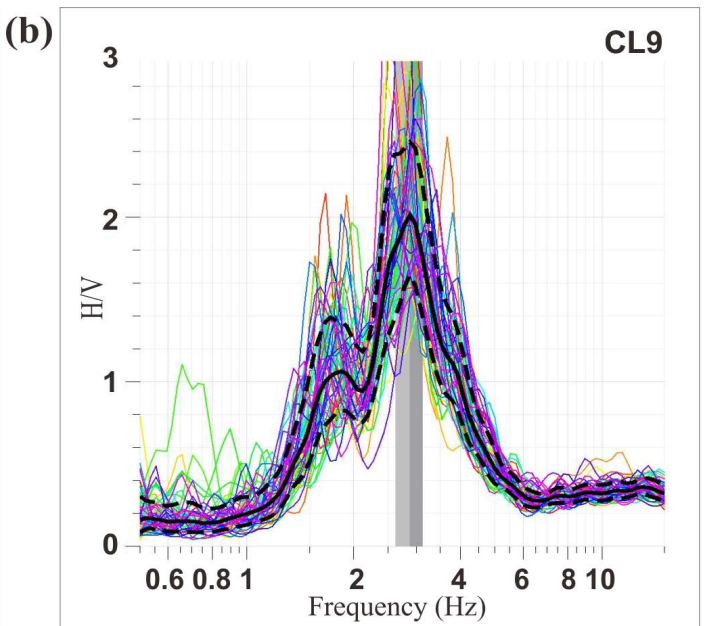

Unclear sharp peak

(d)

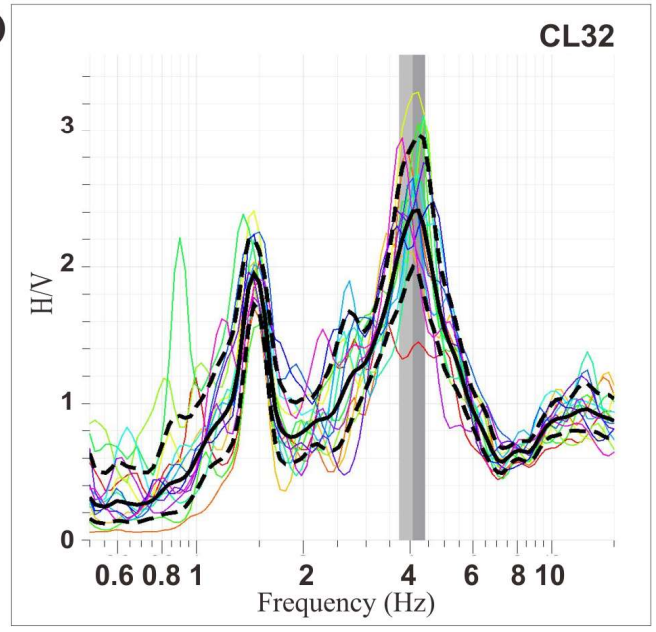

Unclear two peak

Gambar 4. Beberapa karakteristik kurva H/V berdasarkan kriteria SESAME European Research Project (SESAME, 2004)

frekuensi dominan $\left(f_{0}\right)$ pada daerah penelitian ini di pengaruhi juga oleh keadaan topografi daerah penelitian.

\section{Analisis faktor amplifikasi $\left(A_{0}\right)$}

Pada penelitian ini didapatkan nilai faktor amplifikasi $\left(A_{0}\right)$ yang berkisar antara 2 hingga 8 seperti yang ditunjukkan pada Gambar 6. faktor amplifikasi $\left(A_{0}\right)$ berkaitan dengan kontras impedansi antar lapisan batuan. Hal ini sesuai dengan pernyataan Mulyatno et al. (2013) dan Sungkono (2011) yang menyatakan bahwa amplifikasi cenderung dipengaruhi oleh faktor geologi meliputi tingkat deformasi dan sifat fisik batuan. Secara umum daerah penelitian tersusun atas endapan vulkanik. Hasil observasi di lapangan menunjukkan batuan yang berada dipermukaan telah mengalami pelapukan. Nilai faktor amplifikasi $\left(A_{0}\right)$ yang tinggi bernilai di atas 5 tersebar di Kecamatan Ngamprah dan Kecamatan Cisarua. Daerah Kecamatan Ngamprah merupakan daerah yang cukup padat penduduk serta terdapat fasilitas transportasi penghubung kota seperti jalan tol dan rel kereta api. Daerah yang memiliki nilai faktor amplifikasi $\left(A_{0}\right)$ yang tinggi ini akan berpotensi mengalami penguatan gelombang saat terjadi gempa bumi dan dapat mengakibatkan kerusakan bangunan yang parah. 


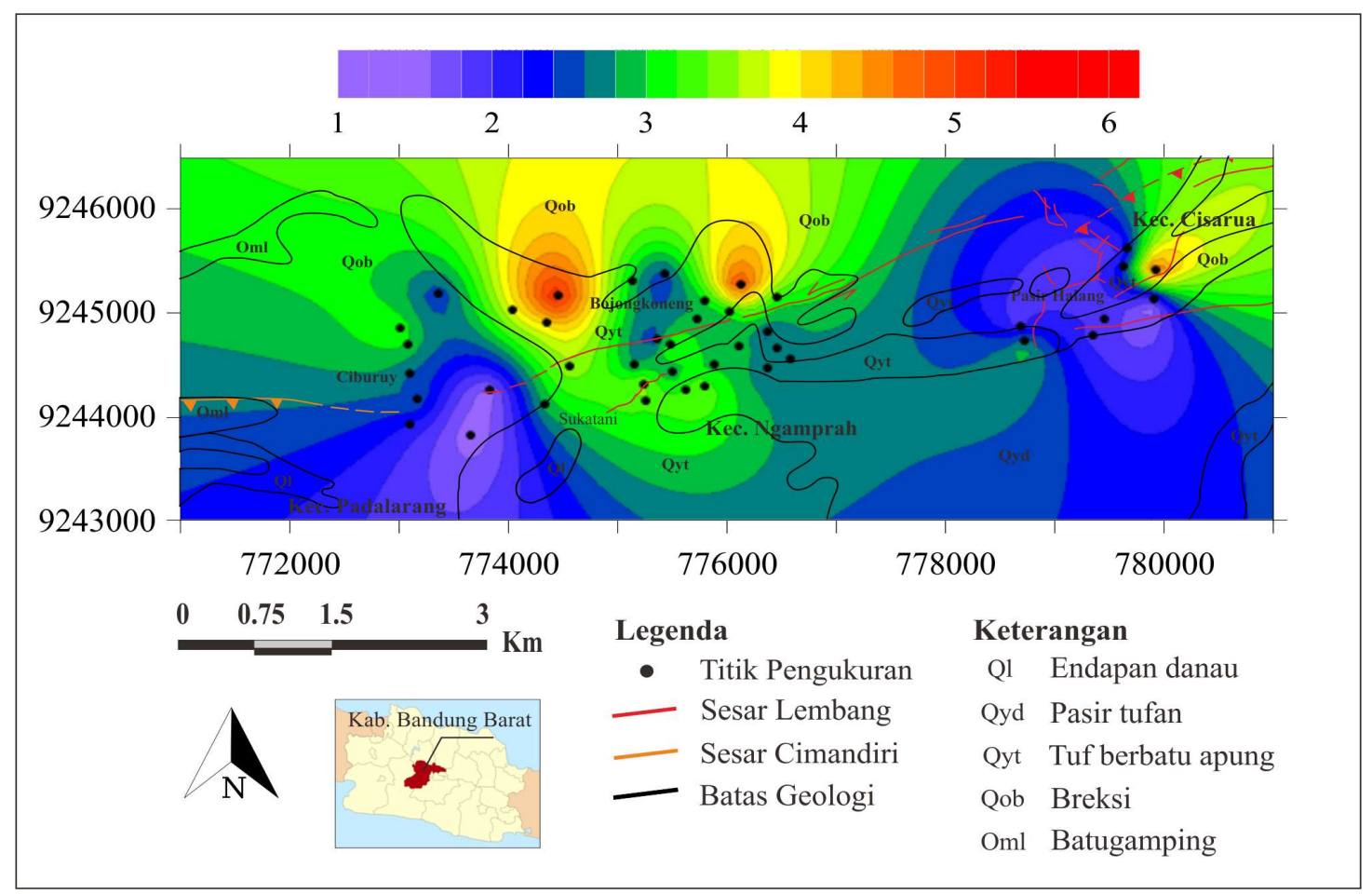

Gambar 5. Peta sebaran nilai frekuensi dominan $\left(f_{0}\right)$.

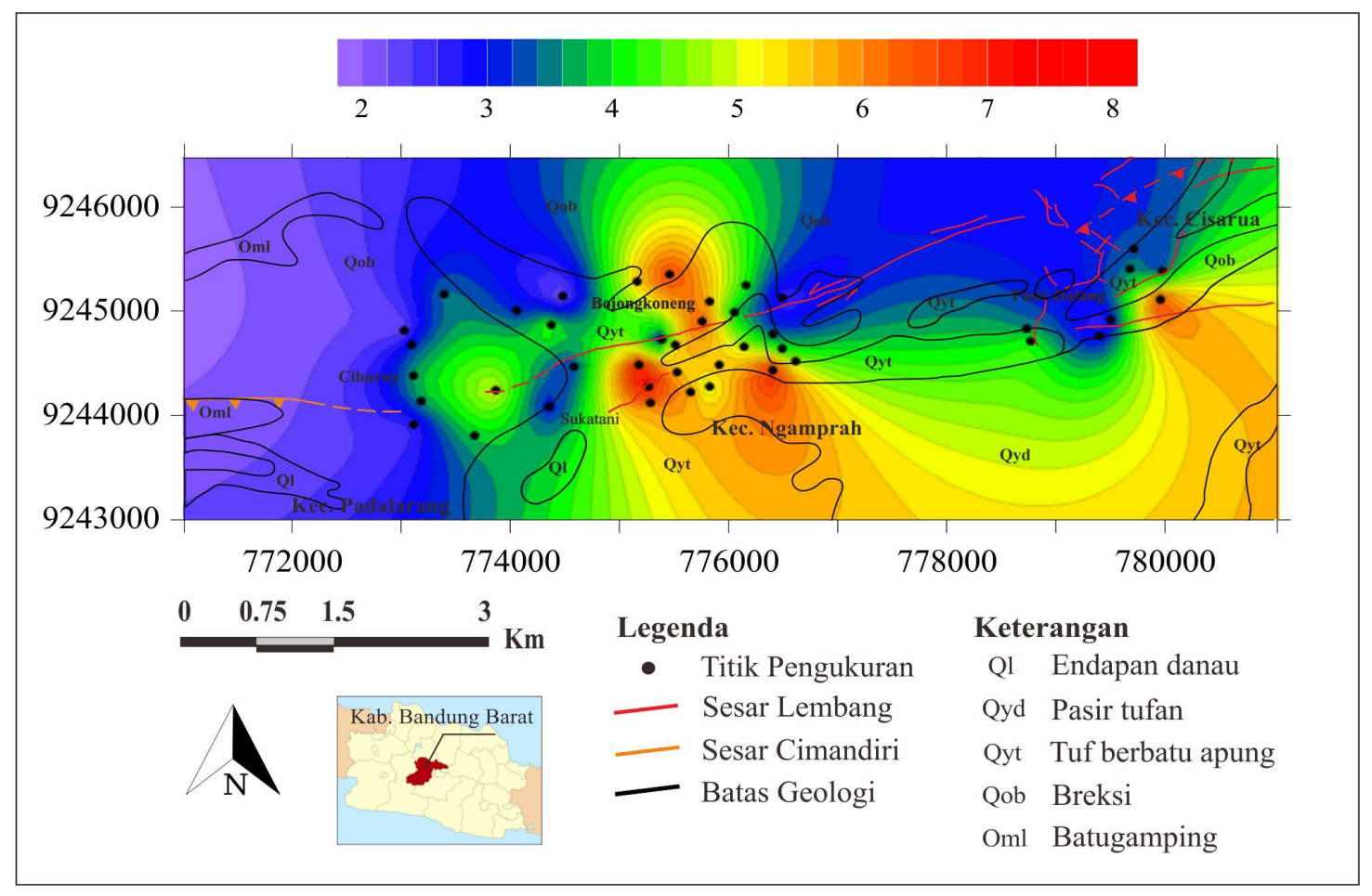

Gambar 6. Peta sebaran nilai faktor amplifikasi $\left(A_{0}\right)$. 


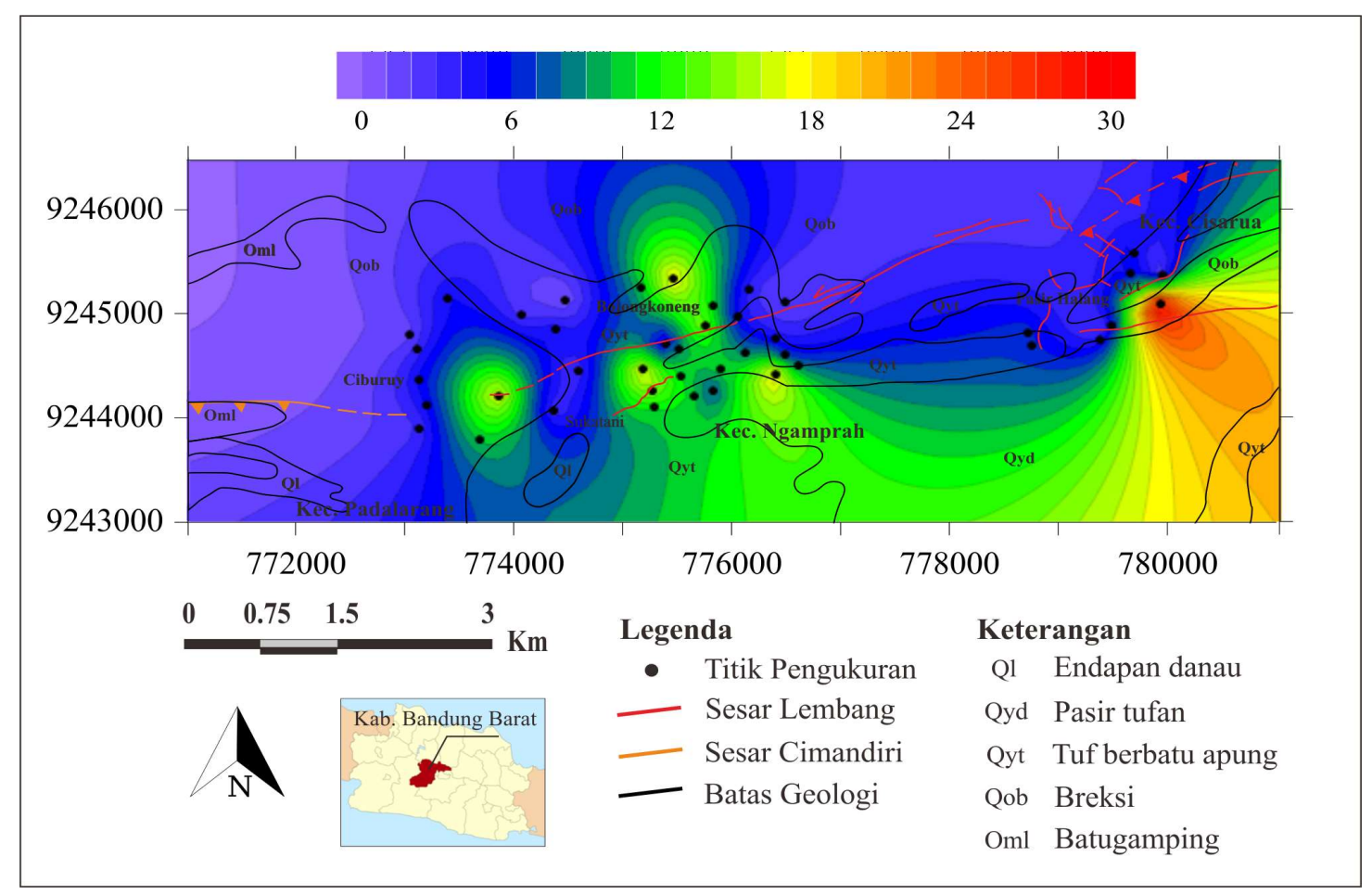

Gambar 7. Peta sebaran nilai indeks kerentanan seismik $\left(K_{g}\right)$.

\section{Analisis indeks kerentanan seismik $\left(K_{g}\right)$}

Nilai indeks kerentanan seismik $\left(K_{g}\right)$ pada daerah penelitian berkisar 1 hingga 30 (Gambar 7). Jika dikorelasikan dengan nilai indeks kerentanan seismik $\left(K_{g}\right)$ daerah Graben Bantul, daerah yang mengalami tingkat kerusakan yang parah akibat gempa bumi Bantul 2006 terjadi pada daerah yang memiliki nilai indeks kerentanan seismik $\left(K_{g}\right)$ di atas 10 (Sunardi et al., 2012). Nakamura (2000) menyatakan daerah yang mengalami kerusakan parah terjadi di dataran aluvial yang tersusun oleh material sedimen yang cukup tebal. Daerah Kecamatan Ngamprah memiliki nilai indeks kerentanan seismik $\left(K_{g}\right)$ yang tinggi berkisar antara 10-15. Daerah tersebut juga memiliki sedimentasi yang cukup tebal di mana morfologi berbentuk cekungan berada di kaki gunung dan perbukitan. Hal ini menjadikan daerah tersebut berpotensi mengalami kerusakan saat terjadi gempa bumi. Selain itu daerah Kecamatan Cisarua juga memiliki nilai indeks kerentanan seismik $\left(K_{g}\right)$ yang tinggi yaitu berkisar antara 20-30. Daerah tersebut memiliki morfologi pegunungan dan berada disekitar segmen Sesar Lembang sehingga daerah ini juga perlu diwaspadai saat terjadi gempa bumi.

\section{PEMBAHASAN}

Jika dilihat dari sebaran nilai frekuensi dominan $\left(f_{0}\right)$ dan faktor amplifikasi $\left(A_{0}\right)$, tidak ada hubungan spesifik yang menyatakan perbandingan kedua nilai tersebut. Berdasarkan Gambar 5 dan Gambar 6, nilai frekuensi dominan $\left(f_{0}\right)$ dan faktor amplifikasi $\left(A_{0}\right)$ saling independen. Nilai frekuensi dominan $\left(f_{0}\right)$ cenderung dipengaruhi oleh litologi dan topografi daerah penelitian, sedangkan nilai faktor amplifikasi $\left(A_{0}\right)$ dipengaruhi oleh deformasi batuan serta pelapukan. Dalam upaya mitigasi informasi nilai frekuensi dominan $\left(f_{0}\right)$ sangat diperlukan dalam perencanaan pembangunan. Struktur bangunan yang memiliki nilai frekuensi yang sama dengan frekuensi dominan $\left(f_{0}\right)$ akan mengalami resonasi saat terjadi gempa bumi. Sehingga saat terjadi gempa bumi efek resonasi tersebut dapat meningkatkan risiko kerusakan bangunan. Selain itu Nakamura (2000) juga menyatakan adanya korelasi antara nilai frekuensi dominan $\left(f_{0}\right)$ dan faktor amplifikasi $\left(A_{0}\right)$ dengan tingkat kerusakan bangunan akibat gempa bumi. Kerusakan bangunan terjadi pada daerah yang memiliki nilai faktor amplifikasi $\left(A_{0}\right)$ yang tinggi serta berasosiasi dengan frekuensi dominan $\left(f_{0}\right)$ rendah. 
Berdasarkan klasifikasi Nakamura (2000), daerah yang memiliki nilai indeks kerentanan seismik $\left(K_{g}\right)$ sedang hingga tinggi berada di Kecamatan Ngamprah dan Kecamatan Cisarua. Sedangkan daerah Kecamatan Padalarang memiliki indeks kerentanan seismik $\left(K_{g}\right)$ relatif rendah hingga sedang. Selain itu daerah disekitar jalan tol dan rel kereta api (Bojongkoneng dan Sukatani) sangat rentan terhadap efek lokal saat terjadi gempa bumi. Hal ini disebabkan karena daerah tersebut memiliki nilai fekuensi dominan yang rendah dan faktor amplifikasi $\left(A_{0}\right)$ yang tinggi sehingga berpotensi mengalami penguatan gelombang saat terjadi gempa bumi.

\section{KESIMPULAN}

Distribusi frekuensi dominan $\left(f_{0}\right)$ di wilayah penelitian terbagi kedalam dua zona dengan rentang frekuensi 1,4 hingga $3,5 \mathrm{~Hz}$ dan 3,5 hingga $6 \mathrm{~Hz}$. Hasil penelitian menunjukkan bahwa nilai frekuensi dominan $\left(f_{0}\right)$ dan faktor amplifikasi $\left(A_{0}\right)$ saling independen. Nilai frekuensi dominan $\left(f_{0}\right)$ pada daerah penelitian cenderung dipengaruhi oleh kondisi topografi sedangkan nilai faktor amplifikasi $\left(A_{0}\right)$ cenderung dipengaruhi oleh deformasi batuan dan pelapukan. Nilai faktor amplifikasi $\left(A_{0}\right)$ pada daerah penelitian berkisar antara 2 hingga 8. Daerah dengan faktor amplifikasi $\left(A_{0}\right)$ yang tinggi berada di daerah Kecamatan Ngamprah dan Kecamatan Cisarua dengan nilai faktor amplifikasi $\left(A_{0}\right)$ berkisar antara 5 hingga 8. Daerah tersebut merupakan kawasan padat penduduk dan terdapat fasilitas penghubung antarkota yang menjadikan daerah tersebut sangat rentan mengalami kerusakan akibat gempa. Selain itu berdasarkan klasifikasi Nakamura (2000) daerah dengan indeks kerentanan seismik $\left(K_{g}\right)$ sedang hingga tinggi berada di Kecamatan Ngamprah dan Kecamatan Cisarua, sedangkan indeks kerentanan seismik $\left(K_{g}\right)$ pada daerah Kecamatan Padalarang relatif rendah hingga sedang.

\section{UCAPAN TERIMA KASIH}

Terima kasih kepada Pusat Penelitian Geoteknologi LIPI Bandung yang telah memfasilitasi penelitian ini dengan instrumen mikrotremor.

\section{KONTRIBUSI PENULIS}

Semua penulis dalam makalah ini adalah kontributor utama dan mempunyai kontribusi yang sama dalam penulisan makalah ini.

\section{DAFTAR PUSTAKA}

Daryono, 2013. Indeks kerentanan seismik berdasarkan mikrotremor pada setiap satuan bentuk lahan di zona Graben Bantul, Daerah Istimewa Yogyakarta. Jurnal Riset Daerah, XII(1), 1753-1777.

Daryono, M. R., Natawidjaja, D. H., Sapiie, B., Cummins, P., 2019. Earthquake geology of the Lembang Fault, West Java, Indonesia. Tectonophysics, 751, 180-191.

Mulyatno, B. S., Marjiyono, Setianegara, R., 2013. Penentuan zona rawan guncangan bencana gempa bumi berdasarkan analisis amplifikasi HVSR mikrotremor dan analisis periode dominan daerah Liwa dan sekitarnya. Geofisika Eksplorasi, 2(1), 30-40.

Nakamura, Y., 1989. A method for dynamic characteristics estimation of subsurface using microtremor on the ground surface. Quarterly Report Railway Tech. Res. Inst., 30, 25-30.

Nakamura, Y., 2000. Clear identification of fundamental idea of Nakamura's technique and its application. The 14th World Conference on Earthquake Engineering, Auckland.

Parolai, S., Grunthal, G., Wahlstrom, R., 2007. Site-specific response spectra from the combination of microzonation with probabilistic seismic hazard assessment-An example for the Cologne (Germany) area. Soil Dynamics and Earthquake Engineering, 27(1), 49-59.

SESAME, 2004. Guidelines For The Implementation Of The H/V Spectral Ratio Technique on Ambient Vibrations. Europe: SESAME European research project.

Silitonga P. H., 1973, Peta Geologi Lembar Bandung, Jawa, Pusat Penelitian dan Pengembangan Geologi, Dirjen Geologi dan Sumberdaya Mineral,Bandung 
Sudjatmiko, 1972. Peta Geologi Lembar Cianjur, Jawa, skala 1:100.000. Direktorat Geologi, Bandung.

Sunardi, B., Daryono, Arifin, J., Susilanto, P., 2012. Kajian potensi bahaya gempa bumi daerah Sumbawa berdasarkan efek tapak lokal. Jurnal Meteorologi dan Geofisika, 13(2), 131-137.

Sungkono, 2011. Inversi terpisah dan simultan dispersi gelombang Rayleigh dan Horizontal-
to-Vertical Spectra Ratio menggunakan algoritma genetik, Tesis, Institut Teknologi Sepuluh November, Surabaya.

Van Bemmelen, R.W. 1934. Geological of Bandung. Bandung: Geologi Tata Lingkungan

Van Bemmelen, R.W., 1949. The Geology of Indonesia. Government Printing Office, The Hague, Netherlands (732 p). 